\title{
SIMULTANEOUS DETECTION OF NEISSERIA MENINGITIDIS, HAEMOPHILUS INFLUENZAE AND STREPTOCOCCUS SP. BY POLYMERASE CHAIN REACTION FOR THE DIAGNOSIS OF BACTERIAL MENINGITIS
}

\author{
Luciane Failace ${ }^{1}$, Mario Wagner ${ }^{2}$, Marisa Chesky³, \\ Rosana Scalco ${ }^{3}$, Luiz Fernando Jobim ${ }^{4}$
}

\begin{abstract}
The simultaneous detection of Neisseria meningitidis, Haemophilus influenzae, and Streptococcus $s p$. was assessed by polymerase chain reaction (PCR) for the diagnosis of bacterial meningitis, as well as the applicability of PCR as a routine test. A cohort study was carried out with 182 children (2 months to 12 years of age) with suspicion of bacterial meningitis. Routine tests identified the etiologic agent in 65/84 children whose clinical status and laboratory findings suggested the presence of bacterial meningitis. Bacterial meningitis was ruled out in 98 children. In 19 children, the etiologic diagnosis was not possible using standard methods; in 14 of these patients, the etiologic agent was identified by PCR ( $N$. meningitidis $=12 ; \mathrm{H}$. influen $z a e=1$; St reptococcus sp.=1). The sensitivity of PCR was $88.1 \%$; specificity, $99.0 \%$; positive predictive value, $98.7 \%$; and negative predictive, $90.1 \%$. PCR is a useful complementary diagnostic technique, especially when Gram stain, culture, or antigenic detection are negative or inconclusive.
\end{abstract}

KEY WORDS: polymerase chain reaction (PCR), bacterial meningitis, cerebrospinal fluid (CSF).

\begin{abstract}
Detecção simultânea da Neisseria meningitidis, Haemophilus influenzae e Streptococcus sp. pela reação em cadeia da polimerase no diagnóstico das meningites bacterianas

RESUMO - Avaliamos o desempenho da reação em cadeia da polimerase (PCR) para detecção simultânea da Neisseria meningitidis, Haemophilus influenzae e Streptococcus sp. no diagnóstico das meningites bacterianas e sua aplicabilidade na rotina diagnóstica. Foi realizado um estudo de coorte com 182 crianças apresentando suspeita de meningite bacteriana. Em 84, havia alterações clínicas e laboratoriais sugestivas de meningite bacteriana. Destas, 65 tiveram o agente etiológico identificado pelos métodos laboratoriais de rotina e 19 ficaram sem diagnóstico etiológico. Em 98 pacientes foi excluído o diagnóstico de meningite bacteriana. Analisando o desempenho da PCR encontramos sensibilidade de $88,1 \%$, especificidade de $99,0 \%$ e valores preditivos positivo e negativo de $98,7 \%$ e $90,1 \%$ respectivamente. Nos 19 pacientes com meningite bacteriana mas sem diagnóstico etiológico a PCR detectou microrganismos em 14, sendo $12 \mathrm{~N}$. meningitidis, um $\mathrm{H}$. influenzae e um $\mathrm{S}$ t reptococcus sp. A PCR possui o potencial de poder aumentar os índices de identificação das técnicas tradicionais, principalmente nas situações onde a microscopia direta, cultura ou identificação antigênica são negativos ou inconclusivos.
\end{abstract}

PALAVRAS-CHAVE: reação em cadeia da polimerase (PCR), meningite bacteriana, líquido cefalorraquidiano (LCR).

Acute bacterial meningitis is responsible for most infections affecting the central nervous system (CNS). Close to two-thirds of all cases occur among child ren, and Haemophilus influenzae, Neisseria meningitidis, and Streptococcus pneumoniae are the pathogens responsible for 80 to $90 \%$ of the cas- $\mathrm{es}^{1,2}$. A rapid and precise etiologic diagnosis of bacterial meningitis is essential to determine adequate treatment, and it can also significantly reduce mortality and the risk for long-term sequelae ${ }^{3}$.In epidemiological terms, the diagnosis of bacterial meningitis may indicate the need for selective immu-

Hospital de Clínicas de Porto Alegre, Universidade Federal do Rio Grande do Sul, Porto Alegre RS, Brazil (UFRS); ${ }^{1}$ Pediatric Immunologist; ${ }^{2}$ Associate Professor, Social Medicine, UFRS, PhD in Epidemiology, London University; ${ }^{3}$ Biochemist, Immunology Unit; ${ }^{4}$ Associate Professor, Internal Medicine Department, UFRS, Chief, Immunology Unit, Hospital de Clínicas de Porto Alegre, Scientific Director, Laboratório DNA Reference, Brazil. Financial support was provided by Fundação de Amparo à Pesquisa do Rio Grande do Sul (FAPERGS). 
nization of a community, such as by chemoprevention and vaccination of the contacts of patients carrying meningococcal disease ${ }^{4}$.

Among the routine tests used for the etiologic diagnosis of bacterial meningitis, bacterial culture is considered the gold standard. However, this is a time-consuming technique, which requires viable microorganisms for cultivation, and its sensitivity is directly affected by the start of antibiotic treatment before spinal tap ${ }^{5}$. Other faster tests, such as latex agglutination, have a lower sensitivity and p resent reliable results only with samples containing more than $105 \mathrm{CFU} / \mathrm{mL}^{6}$. Currently, molecular biology techniques, such as PCR, are being widely used for the etiologic diagnosis of CNS infections ${ }^{7}$. In 1991, Kristiansen et al. detected the presence of N. meningitidis DNA in the culture-negative cerebrospinal fluid (CSF) specimen of a patient with meningococcal disease after she had received antibiotic treatment ${ }^{8}$. In 1992, Ni et al. studied the use of PCR in diagnosing meningococcal meningitis; results indicated specificity and sensitivity of $91 \%$. Neither sensitivity nor specificity were affected by p revious antibiotic treatment ${ }^{9}$. In 1994, Radstro m et al. described a nested PCR strategy for the simultaneous detection of Neisseria meningitidis, Hae mophilus influenzae, and Streptococcus sp. ${ }^{10}$ in CSF. That study showed that it is possible to simultaneously and efficiently amplify the three main pathogens that cause bacterial meningitis. However, it also revealed certain difficulties associated with the technique, such as false-positive results due to contamination, and false-negative results due to the presence of PCR inhibitors in CSF, which still compromise diagnostic reliability ${ }^{10-13}$. Additional studies correlating clinical and laboratory findings to PCR results are essential to confirm the diagnostic value of PCR.

The present study was carried out in order to assess the simultaneous detection of Neisseria me ningitidis, Haemophilus influenzae, and Strepto coccus sp. by PCR for the diagnosis of bacterial meningitis. The study also evaluated the applicability of PCR as a routine laboratory test.

\section{METHOD}

A cohort study was carried out with children between 2 months and 12 years of age, with suspicion of bacterial meningitis at three public hospitals in the city of Porto Alegre, State of Rio Grande do Sul, Brazil: Hospital de Clínicas de Porto Alegre, Hospital da Criança Santo Antônio, and Hospital da Criança Conceição. Most pediatric cases in the region are treated at these hospitals.
The study was submitted to and approved by the Research Ethics Committees of the participating hospitals. Children with suspected bacterial meningitis were included in our study after an informed consent form was signed by a parent or guardian. A $0.5 \mathrm{~mL}$ aliquot of CSF was separated during spinal tap or after the CSF was received in the laboratory. Specimens were stored at $-20^{\circ} \mathrm{C}$ until PCR was performed.

The signs and symptoms of bacterial meningitis vary depending on the age group. In preschool and school age children, the predominant symptoms include meningeal irritation and increase of intracranial pressure expressed as neck stiffness (Kernig's and Brudzinski's signs). In younger children, these symptoms may be absent, with predominance of unspecific signs of infection. In these cases, meningitis was considered in the presence of fever, lethargy, irritability and sleepiness, especially if associated with signs of meningeal irritation or increased intracranial pressure.

Alterations in CSF, such as leukocytosis with predominance of polymorphonuclears, CSF glucose concentration below $40 \mathrm{mg} / \mathrm{dL}$ and increased CSF protein (100$500 \mathrm{mg} / \mathrm{dL}$ ) are considered to be suggestive of bacterial meningitis. Diagnostic confirmation is based on the identification of the etiological agent through direct microscopy (Gram), culture, latex agglutination or counterimmunoelectrophoresis. Leukocytosis with predominance of lymphocytes, normal or increased CSF glucose and increased proteins suggest viral meningitis.

Clinical history and results of physical examination we re reviewed. Patients were followed until discharge from the hospital. The results of routine CSF analysis (diffe rential cell count; glucose; protein; Gram stain; bacterial culture; and latex agglutination) were obtained from the medical chart during hospitalization, or directly from the laboratory. Counterimmunoelectrophoresis was carried out at a state-run laboratory (Laboratório Central do Estado do Rio Grande do Sul); these results were obtained from the State Department of Health.

In the present study, the gold standard for diagnosing bacterial meningitis included clinical signs and symptoms (as previously described), course of disease (antibiotic therapy, length of admission, neurological sequelae), and routine laboratory results (CSF analysis: differential cell count; glucose; protein; Gram stain; bacterial culture; latex agglutination and counterimmunoelectrophoresis). According to these criteria, patients were divided into three groups:

Group I - Clinical indication of bacterial meningitis, positive laboratory results (leukocytosis with predominance of polymorphonuclears, low CSF glucose concentration and increased CSF protein), and etiologic agent diagnosed by routine methods (i.e. Gram stain, bacterial culture, latex agglutination, and counterimmunoelectrophoresis); 


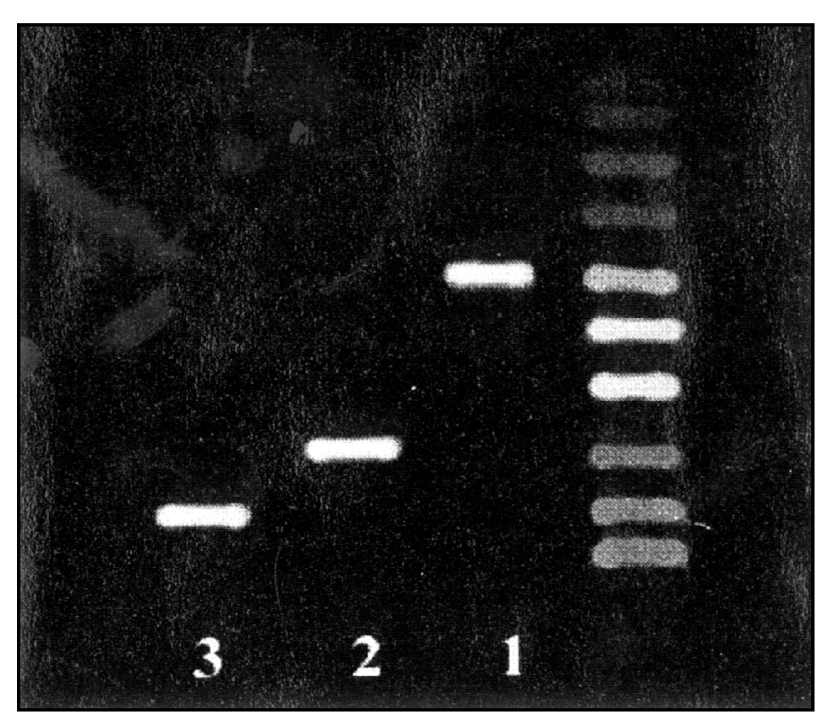

Fig. Electro $p$ h o resis of PCR amplification products in agarose gel (2\%). Results are compared to molecular weight markers and DNA sequences of Streptococcus sp. (1), H. influenzae (2), and $N$. meningitidis (3).

G roup II - Clinical indication of bacterial meningitis, positive laboratory results, and unsuccessful diagnosis of etiologic agent by routine methods;

G roup III - Clinical indication of bacterial meningitis, diagnosis of bacterial meningitis ruled out by course of disease, and negative laboratory results.

PCR sensitivity, specificity, and predictive values were calculated by comparing the results for groups I+II versus group III. It is important to stress that the diagnosis of meningitis and the distribution in the groups was independent, i.e., blinded for the result of PCR.

We employed the seminested multiplex PCR technique for the simultaneous detection of $N$. meningitidis, $H$. influenzae, and Streptococcus sp. A region of bacterial gene 165 rRNA was amplified. Species-specific primers were used along with primers complementary to universal regions U3 and U8 of gene 16S rRNA, in a two-stage PCR assay. In the first stage, amplification was performed using extemal universal primers (u3, ru8). A generic bacterial amplicon was generated, not specific to the type of bacterium present in the specimen. The second stage combined th ree specific primers - one for each type of bacterium with the ru8 universal primer, generating species-specific amplicons with different molecular weights.

In the first stage, the PCR reaction contained $\left(\mathrm{NH}_{4}\right)_{2} \mathrm{SO}_{4}$ (16 mM); Tris- $\mathrm{HCl}\left(67 \mathrm{mM}\right.$; pH 8.8 at $\left.25^{\circ} \mathrm{C}\right) ; 0.01 \%$ Tween$20(\mathrm{w} / \mathrm{v}) ; \mathrm{MgCl} 2$ (1.5 mM); triphosphate deoxyribonucleoside mixture $(0.25 \mathrm{mM})$; external primers (at $0.1 \mu \mathrm{M})$ synthesized according to previously published sequences ${ }^{10}$; and polymerase DNA enzyme (0.625 U). During this first step, $10 \mu \mathrm{L}$ of CSF were added. DNA extraction from hemorrhagic or xanthochromic CSF specimens, and from specimens with high leukocyte concentration (causing turbidi- ty) was carried out using the QIAamp kit (70 $\mu \mathrm{L}$ CSF specimen). Other CSF specimens were submitted to PCR directly, without any treatment. The final reaction volume was $50 \mu \mathrm{L}$. Amplification was done on a 9600 Perkin Elmer thermocycler. The initial denaturation period was of $1 \mathrm{mi}-$ nute and 40 seconds at $94^{\circ} \mathrm{C}$, followed by 33 incubation cycles (20 seconds each) at $94^{\circ} \mathrm{C}, 60^{\circ} \mathrm{C}$ and $72^{\circ} \mathrm{C}$.

The second amplification stage employed speciesspecific primers and the universal ru8 primer in a mixture identical to that of the first stage. The final reaction volume was $25 \mu \mathrm{L}$, and we used $2 \mu \mathrm{L}$ from the first reaction as specimen. Denaturation was perf o rmed for 45 seconds at $94^{\circ} \mathrm{C}$, followed by 33 (15-second cycles) at $94^{\circ} \mathrm{C}, 15$ seconds of annealing at $55^{\circ} \mathrm{C}$, and $20 \mathrm{sec}-$ onds of polymerization at $72^{\circ} \mathrm{C}$. Some procedures were followed to avoid contamination, such as using aerosolresistant tips, working in four distinct environments, including negative controls, and submitting the reagent mixtureto UV radiation $(254 \mathrm{~nm}$ ) for 15 minutes before adding CSF. All positive specimens were retested for confirmation of the results.

A $10 \mu \mathrm{L}$ specimen from the second PCR reaction was run in an ethidium bromide-stained $2 \%$ agarose gel. Amplification products were identified following electrophoresis. Specimens were visualized using UV transillumination. Specific $N$. meningitidis (700 bp), H. influenzae (500 bp), and Streptococcus sp. (300 bp) bands were compared to the respective controls or to molecular weight markers (Figure).

Me a su rements of PCR perf o rmance were expressed as percentages with their respective $95 \%$ confidence intervals $(95 \% \mathrm{Cl})$. Confidence intervals were calculated by binomial distribution. Due to the asymmetric distribution of the data, the Kruskal-Wallis test was used to analyze the comparisons between groups I, II and III. The nonparametric multiple comparison test proposed by Dunn was used to assess differences between the groups.

\section{RESULTS}

During the 18 months of the study, we analyzed 182 patients with suspected bacterial meningitis. In 65 patients, the diagnosis of bacterial meningitis was confirmed by identification of the etiologic agent using routine laboratory tests (group I). $\mathrm{Ni-}$ neteen patients presented clinical and laboratory indication of bacterial meningitis without identification of the etiologic agent by standard tests ( $g$ roup II). In the remaining 98 patients, the course of the disease and laboratory results ruled out a diagnosis of bacterial meningitis (group III). The clinical and laboratory characteristics of the three groups are presented in Table 1.

Among the 65 patients from group I, 29 cases (44.6\%) were caused by $H$. influenzae, 21 (32.3\%) by $N$. meningitidis, and $15(23.1 \%)$ by Streptococcus sp. PCR identified the correct pathogen in 60 of the 
Table 1. Clinical and laboratory characteristics of groups I, II, and III.

\begin{tabular}{lcccc}
\hline Variable & Group I $(\mathrm{n}=65)$ & Group II $(\mathrm{n}=19)$ & Group III $(\mathrm{n}=98)$ & $\mathrm{p}$ \\
\hline Age (months) & $12^{\mathrm{a}}(5-36)$ & $45^{\mathrm{b}}(12-84)$ & $48^{\mathrm{b}}(24-84)$ & $<0.001$ \\
$\begin{array}{l}\text { Duration of hospital stay (days) } \\
\text { \% of patients receiving antibiotics }\end{array}$ & $11^{\mathrm{a}}(10-16)$ & $10^{\mathrm{a}}(10-11)$ & $2^{\mathrm{b}}(2-3)$ & $<0.001$ \\
$\quad$ & & & & \\
$\quad$ before spinal tap & $14^{\mathrm{a}, \mathrm{b}}(21.5 \%)$ & $8^{\mathrm{a}}(42.1 \%)$ & $13^{\mathrm{b}}(13.3 \%)$ & 0.012 \\
CSF leukocytes/mm & $1320^{\mathrm{a}}(597-3400)$ & $1200^{\mathrm{a}}(700-11700)$ & $313^{\mathrm{b}}(85-604)$ & $<0.001$ \\
$\%$ neutrophils & $88^{\mathrm{a}}(77-93)$ & $90^{\mathrm{a}}(81-93)$ & $15^{\mathrm{b}}(4-64)$ & $<0.001$ \\
CSF glucose $(\mathrm{mg} / \mathrm{dL})$ & $13^{\mathrm{a}}(2-55)$ & $48^{\mathrm{a}}(1-62)$ & $59^{\mathrm{b}}(53-70)$ & $<0.001$ \\
CSF protein $(\mathrm{mg} / \mathrm{dL})$ & $200^{\mathrm{a}}(120-280)$ & $150^{\mathrm{a}}(88-190)$ & $43^{\mathrm{b}}(32-61)$ & $<0.001$ \\
\hline
\end{tabular}

All values are expressed as medians (interquartile range), except for percentage of patients taking antibiotics. Superscript letters indicate statistically significant differences.

Table 2. Sensitivity of routine laboratory tests for the etiologic diagnosis of patients with bacterial meningitis.

\begin{tabular}{|c|c|c|c|c|c|c|}
\hline Method & No. tests & $\begin{array}{c}\text { Sensitivity } \\
\text { (groups I and III) }\end{array}$ & Cl $95 \%$ & No. tests & $\begin{array}{c}\text { Sensitivity } \\
\text { (groups I, II, and III) }\end{array}$ & $\mathrm{Cl} 95 \%$ \\
\hline PCR & 65 & $92.3 \%$ & $82.2-97.1$ & 84 & $88.1 \%$ & $78.8-93.8$ \\
\hline Gram stain & 65 & $81.5 \%$ & $70.0-90.1$ & 84 & $63.3 \%$ & $52.4-72.9$ \\
\hline Culture & 65 & $81.5 \%$ & $70.0-90.1$ & 84 & $63.3 \%$ & $54.4-72.9$ \\
\hline Latex agglutination & 40 & $75.0 \%$ & $58.8-87.3$ & 50 & $60.0 \%$ & $46.0-72.8$ \\
\hline $\mathrm{Cl}^{*}$ & 36 & $52.8 \%$ & $35.5-69.6$ & 46 & $41.3 \%$ & $27.8-55.9$ \\
\hline
\end{tabular}

*counterimmunoelectrophoresis.

65 cases. However, PCR did not identify the correct pathogen in three cases of $\mathrm{N}$. meningitidis and in two cases of Streptococcus sp. Among the $98 \mathrm{pa}$ tients from group III, PCR was negative in 97 CSF specimens. There was one false-positive result indicating $N$. meningitidis DNA.

Among the 19 patients from group II, PCR identified pathogens in 14 specimens. Twelve specimens contained $N$. meningitidis DNA, one specimen contained $H$. influenzae DNA, and one specimen contained Streptococcussp. DNA. In group II, $42.1 \%$ of the patients had started antibiotic treatment before spinal tap, compared to $21.5 \%$ in group I and $13.3 \%$ in group III.

The sensitivity of PCR in groups I and III was 92.3\% (95\% Cl: 82.2-97.1), and the specificity was 99.0\% (95\% Cl: 93.6-99.9). The positive predictive value was $98.4 \%$ (95\% Cl: 90.0-99.9), and the negative predictive value was $95.1 \%(95 \% \mathrm{Cl}: 88.4-$ 98.2). When group II patients were included in the assessment of PCR performance, sensitivity dropped to $88.1 \%$ (95\% Cl: $78.8-93.8)$, and the negative predictive value was reduced to $90.1 \%$ (95\% Cl: 83.1 95.2). Nevertheless, both the specificity and the positive predictive value remained practically the same: 99.0\% (95\% Cl: 93.6-99.0) and 98.7\% (95\% Cl: 91.899.9), respectively.

When assessing groups I and III, there was no statistically significant diff e rence between sensitivity of PCR, Gram stain, culture, and latex agglutination. When group II patients were included, the sensitivity of PCR was significantly higher than that of the other tests (Table 2).

\section{DISCUSSION}

In general, the number of cases of bacterial meningitis whose etiologic agent is not identified is still significant. Several factors interf e re with the recovery of micro organisms from CSF, such as previous antibiotic treatment, inadequate collection and storage of culture specimens, and reduced number of bacteria in CSF. Tests for detecting bacterial antigens, such as latex agglutination and counterimmunoelectrophoresis, may assist in the diagnosis of bacterial meningitis. However, although these tests are fast and not affected by previous antibiotic treatment, their sensitivity is limited. The use of molecular biology techniques, such as PCR, for the etiologic diagnosis of CNS infections is under study. It is expected that such techniques will have a higher sensitivity and specificity for diagnosing meningitis.

We assessed the accuracy of the seminested PCR technique for the simultaneous detection of the three main pathogens which cause bacterial meningitis: N. meningitidis, $H$. influenzae, and Strep tococcus sp. Due to the absence of an absolute gold standard, in the present study clinical status, course of disease, CSF analysis, and identification of etiologic agent by routine tests (Gram stain, culture, latex agglutination, and counterimmunoelectrophoresis) were established as the gold standard for the diagnosis of bacterial meningitis. Since the etiologic agent is not identified in many patients (especially in those receiving antibiotics before spinal tap), we later decided to consider another gold 
standard, i.e., the clinical and laboratory diagnosis of bacterial meningitis, regardless of etiologic identification.

When the etiologic diagnosis of bacterial meningitis was used as the gold standard, group II patients (clinical and laboratory indication of bacterial meningitis; unsuccessful etiologic identification by routine tests) were excluded from the calculation of PCR accuracy, and consequently these results may be overestimated. The inclusion of patients with clinical and laboratory indication of bacterial meningitis whose etiologic identification proved unsuccessful through routine laboratory tests reveals a PCR accuracy that is closer to what would be expected if this assay were used routinely for the diagnosis of bacterial meningitis; there is a statistically nonsignificant drop in sensitivity and negative predictive value, whereas specificity and positive predictive value remain practically unchanged.

PCR was the only test that was capable of identifying the etiologic agent in 14 patients from g roup II. In $63 \%$ of these patients, $N$. meningitidis DNA was detected in CSF. The notion that over half of the bacterial meningitis cases without etiologic identification were caused by $N$. meningitidis is important both clinically and epidemiologically, and allows a more adequate management of patients and contacts. The fact that antibiotic use before spinal tap was more frequent in group II underscores the importance of PCR in the identification of the etiologic agent in meningitis.

PCR did not identify pathogens in five cases of bacterial meningitis with etiologic diagnosis by routine tests, a fact that points to the presence of PCR inhibitors in CSF. PCR inhibitors had been detected in some hemorrhagic, xanthochromic, and high leukocyte-concentration CSF specimens, and DNA extraction techniques were used in an attempt to remove the inhibitors. In these five specimens, there had been no CSF alterations indicating the need for extraction, and, therefore, CSF was di rectly submitted to PCR. At the end of the study, these specimens were submitted to DNA extraction and resubmitted to PCR. After extraction, PCR identified pathogens in three of the five specimens with previously negative results. This suggests that purification and concentration $(70 \mu \mathrm{L})$ of bacterial DNA in CSF using extraction techniques may im$p$ rove the sensitivity of the method. Extraction techniques should be applied to all CSF specimens, regardless of their macroscopic aspect. While the detection of PCR inhibitors could indicate the need for an internal control, the use of a multiplex reaction could lead to difficulties in the interpretation of results.

The high specificity and the positive predictive values found in our study indicate that the pro bability of false-positive PCR results is low, and that $P C R$ detection of pathogens is a strong indicator of bacterial meningitis. In turn, the sensitivity and negative predictive values found in the present study suggest that a diagnosis of bacterial meningitis should not be ruled out when PCR results are negative. Our results suggest that PCR may enhance the diagnostic accuracy of traditional techniques, especially when Gram stain, culture, and antigenic detection tests are negative or inconclusive.

Molecular biology techniques, such as PCR, have a wide range of applications for diagnosis. However, before incorporating PCR into a diagnostic routine, it is necessary to standardize this procedure, to establish strict laboratory quality control measures, and to carry out further studies aimed at establishing PCR accuracy. Finally, PCR should not replace standard tests, rather, it should contribute to more precise and rapid diagnoses.

\section{REFERENCES}

1. Bell WE. Bacterial meningitis in children: selected aspects. Pediatr Clin N Am 1992;39:651-658.

2. Schelch WF III, Ward JI, Band JD, Hightower A, Fraser DW, Broome CV. Bacterial meningitis in the United States, 1978 through 1981: the national bacterial meningitis surveillance study. JAMA 1985;253:1749-1754.

3. Salih MA, Khaleefa OH, Bushara M, et al. Long-term sequelae of childhood acute bacterial meningitis in a developing country: a study from the Sudan. Scand J Infect Dis 1991;166:177-182.

4. Greenwood BM, Wali SS. Control of meningococcal infection in the African meningitis belt by selective vaccination. Lancet 1980;8171:729-732.

5. Gray LD, Fedorko DP. Laboratory diagnosis of bacterial meningitis. Clin Microbiol Rev 1992;2:130-145.

6. Olcén P. Serological methods for rapid diagnosis of Haemophilus influenzae, Neisseria meningitidis and Streptococcus pneumoniae in cere$b$ rospinal fluid: a comparison of coagglutination, immunofluorescence and immunoelectroosmophoresis. Scand J Infect Dis 1978;10:283-289.

7. Jeffery KJM, Bangham CRM. Recent advances in the laboratory diagnosis of central nervous system infections. Curr Opin Infec Dis 1996;9:132-137.

8. Kristiansen B, Ask E, Jenkins A, Fremer C, Radstrom P, Skold O. Rapid diagnosis of meningococcal meningitis by polymerase chain reaction. Lancet 1991;337:1568-1569.

9. Ni H, Knight A, Cartwright K, Palmer WH, McFadden J. Polymerase chain reaction for diagnosis of meningococcal meningitis. Lancet 1992; 340:1432-1434

10. Radstrom P, Backman A, Qian N, Kragsjberg P, Pahlson C, Olcen P. Detection of bacterial DNA in cereb rospinal fluid by an assay for simultaneous detection of Neisseria meningitidis, Haemophilus influenzae, and Streptococci using a seminested PCR strategy. J Clin Microbiol 1994;32:2738-2744.

11. Olcen P, Lantz P, Backman A, Radstrom P. Rapid diagnosis of bacterial meningitis by a seminested PCR strategy. Scand J Infect Dis 1995; 27:537-539.

12. Backman A, Lantz P, Radstrom P, Olcen P. Evaluation of an extended diagnostic PCR assay for detection and verification of the common causes of bacterial meningitis in CSF and other biological samples. Mol Cell Probes 1999;1:49-60.

13. Schuurm an T, de Boer RF, Kooistra-Smid AM, van Zwet AA. Prospective study of use of PCR amplification and sequencing of $16 \mathrm{~S}$ ribosomal DNA f rom cerebrospinal fluid for diagnosis of bacterial meningitis in a clinical setting. J Clin Microbiol 2004;42:734-740. 